\title{
YETIŞTIRME YURDUNDA KALAN ERGENLERIN GELECEK BEKLENTILERI VE SOSYAL DESTEK ALGILARI
}

\section{A. S. Bayoğlu* E. Purutçuoğlu*}

\section{ÖZET}

Bu çalışma 13-18 yaş korunmaya muhtaç ergenlerin sosyal destek algıları ile gelecek beklentilerini belirlemek amacı ile planlanmış ve yürütülmüştür. Araştırma bölgesi Ankara İI Merkezidir. Araştırmanın evrenini SHÇEK Genel Müdürlüğü'ne bağlı Atatürk Çocuk Yuvası ve Kız Yetiştirme Yurdu Müdürlüğü ve Gazi Erkek Yetiştirme Yurdu Müdürlüğü'nde bakım ve korunma altında bulunan ergenler oluşturmaktadır. Araştırma sonucunda, ergenlerin beklentilerinin en çok eğitim, iş ve ekonomik konularla ilişkili olduğunu, en çok yakın arkadaşlarından ve öğretmenlerinden destek aldıkları, ve kız ergenlerin algıladıkları sosyal desteğin erkek ergenlerden daha yüksek olduğu saptanmıştır.

Anahtar Sözcükler: Ergen, yetiştirme yurdu, sosyal destek, gelecek beklentisi

\section{Future Expectations and Perceived Social Support of Adolescents Living in Orphanages}

\section{Abstract}

This study was planned and carried out to determine the adolescent's perceived social supports and future expectations in need of protection in the age of 13-18. The research area is Ankara city center. The population of the study consists of the adolescents under the care and protection in SHÇEK (Social Services and Child Protection Agency). The results of the study indicate that the expectations of adolescents is mostly related to the education, work and economical issues. They more receive social supports from their close friends and teachers. Besides it is illustrated that female adolescents' peceived social support is much more than male adolescents.

Key Words: Adolescent, orphanage, social support, future expectation

\section{Giriş ve Amaç}

Ergenlik fiziksel, psikolojik ve zihinsel değişimlerin yaşandığı zorlu bir süreçtir (Aydemir ve ark 2009). Bu zorlu süreci başarıyla atlatan ergenleri, bu dönemde zorluklar yaşayan ergenlerden ayıran önemli bir özellik ergenlerin hem ebeveynleriyle hem de akranlarıyla oluşturdukları ilişkilerin niteliğidir (Bayraktar 2007).

Yetiştirme yurdunda sevgiden ve ilgiden yoksun olarak büyüyen ergen, gelişimi için gerekli olan deneyimleri kazanmada daha çok zorlanmakta ve çekingen, içine kapanık bir kişilik sergileyebilmektedir (Cebe 2005). Bu sevgiden ve ilgiden yoksun olarak büyüyen 
ergenlerin belirli ilgi, değer ve niteliklere göre oluşan arkadaşlık grupları, gençlerin yetişmesinde etkili olmaktadır (Cılga 1989).

Çocuğa erken yaşlarda sağlanacak deneyimlerle elde edilecek temel bilgi, beceri ve alışkanlıklar, çocuğun daha sonraki öğrenim yaşamının yanı sıra sosyal ve duygusal yaşamını da biçimlendirecek güçtedir ve tesadüflere bırakılamayacak kadar ciddi, bilimsel ve sistematik bir organizasyon ile yönlendirilmesi gerekmektedir (Kürkçüoğlu ve ark 2010).

Özellikle küçük yaşlarda kurum bakımı altına alınmış korunmaya muhtaç çocukların bireysel ilgi ve sevgi gereksinimlerinin karşılanması, her alandaki gelişimlerinin desteklenmesi ve genel olarak nitelikli bir yaşam sürdürebilme imkânı açısından dezavantajlı oldukları söylenebilir. Kurum bakımı altında olmak çoğu zaman sosyal ve pratik intiyaçlar anlamında yoksunlukla eş tutulmuş ve kurumlarda yetişen çocuklarda fiziksel, bilişsel, sosyal ve duygusal alanlarda gelişim bozuklukları ve gelişim gerilikleri görüldüğü ortaya konmuştur (Özdemir ve ark 2008).

Anne, baba ya da hem anne ve babanın ölmesi sonucu korunmaya muhtaç olan çocukların topluma kazandırılması yönünde farklı teknikler kullanılmaktadır. Gelişmiş ülkelerde gençlerin sağlığını korumaya, gençlerde var olan sorunları saptamaya ve bunlara müdahale etmeye yönelik hizmetler her geçen gün artmakta iken, Türkiye'de korunmaya muhtaç çocukların tanımının ve intiyaçlarının bütüncül bir biçimde ele alınamamaktadır. Günümüzde kurum bakımı, grup evleri, koruyucu evleri, evlat edinme ve çocuklara kendi aileleri ve yakın akrabaları yanında hizmet sağlanması biçiminde uygulamalar ülkemizdeki görülen yaygın hizmetlerdir (Karataş ve ark 2004, Yardımcı ve Başbakkal 2008, Kürkçüoğlu ve ark 2010).

Yetiştirme yurdu; kimsesiz ve korunmaya muhtaç çocuklara, gençlere; aile yapısı içinde sağlanamayan toplumsal refah hizmetlerini düzenler. Toplumsal düzeyde ise; aile, çocuk ve gençlik refahına yaklaşımın somutlaştığı örgütsel yapılardır (Şenocak 2010).

Korunmaya muhtaç olan gençlerin kaldıkları yetiştirme yurtlarının onların toplumsallaşma süreci ile sosyal işlevsellik kazanmalarına yardımcı olması, toplumdan izole edilmiş bu grubun tekrar topluma kazandırılmasında, aile uyarıcısının yokluğundan kaynaklanan boşluğu doldurması beklenir (Cılga 1989). Ancak, çocukluk dönemi özellikleri düşünüldüğünde bu tür bakım, olumlu özellikler taşımamakta, çocuğun yetişkinler tarafından desteklenmesi ve yönlendirilmesi işlevini yerine getirememektedir (Akman 2002).

Sosyal destek, bireylerin kendi sosyal ağları içinde önemsendiklerini ve değer verildiklerini hissettikleri, kişisel işlevselliklerini artırabilen, farklı stres kaynakları ile başa çıkmalarında yardımcı olabilen ve istenmeyen sonuçları engelleyebilen bireysel algılardır (Demaray ve ark 2005). Çok boyutlu algılanan sosyal destek kuramsal açıdan arkadaşlar, aile ve birey için anlamlı diğer kişilerden elde edilir (Çeçen 2008). Travmayla baş etmede algılanan sosyal desteğin, aile, arkadaş ve yakın çevreninin sağladığı doğal destekten yararlanmanın oldukça önemli olduğu bilinmektedir (Kartal ve Çetinkaya 2009).

Cobb (1976)'un yaptığı klasik tanıma göre ise sosyal desteğin 3 öğesi; hissedilen sevgi, hissedilen değer ve hissedilen saygıdır. Hissedilen sosyal desteğin boşanmış aile çocukları, öğrenme güçlüğü olan çocuklar ve dezavantajlı çocuklar için daha önemli olduğu düşünülmektedir. Ayrıca, sosyal destek algıları yüksek olan çocuk ve ergenlerin daha az uyum sorunun olduğunu belirtmişlerdir (Cobb 1976).

$\mathrm{Bu}$ çalışmada, 13-18 yaş korunmaya muhtaç ergenlerin aile, arkadaş ve öğretmenlerinden algıladıkları sosyal destek ile geleceğe yönelik beklentileri incelenmiştir. 


\section{Yöntem ve Gereçler}

\section{Örneklem yöntemi ve örnek seçimi}

Araştırma bölgesi Ankara İ Merkezidir. Araştırmanın evrenini SHÇEK Genel Müdürlüğü'ne bağlı Atatürk Çocuk Yuvası ve Kız Yetiştirme Yurdu Müdürlüğü ve Gazi Erkek Yetiştirme Yurdu Müdürlüğü'nde bakım ve korunma altında bulunan ergenler oluşturmaktadır. Araştırmanın yürütüldüğü 03.05.2010-28.05.2010 tarihleri arasında Atatürk Çocuk Yuvası ve Kız Yetiştirme Yurdu'nda bulunan 13-18 yaş grubundaki 112 kız ergenden 51'i ile Gazi Erkek Yetiştirme Yurdu'nda bulunan 13-18 yaş grubundaki 48 erkek ergenden 30'u çalışma yapmaya uygun bulunmuş, araştırmaya toplam 81 ergen dahil edilmiştir. Ergenler araştırmaya dahil edilirken çalışmaya katılmaya istekli bulunmaları ve psikolojik durumları dikkate alınmıştır.

\section{Anket formunun hazırlanması}

Ergenlerin sosyal destek algılarını ölçmek için Malecki ve Demaray (2002) tarafından geliştirilen 3'li Likert tipi (Çok önemli-3, Önemli2, Önemli değil-1) "Ergenlerin sosyal destek algıları" ölçeğine Fikrim yok (0) seçeneği eklenerek kullanılmıştır. Araştırmanın planlama aşamasında Türkiye'de ölçekle ilgili bir geçerlik güvenirlik çalışması bulunamamıştır. Çalışmanın değerlendirilmesi aşamasında ölçeğin Yardımcı ve Başbakkal (2009) tarafından uyarlandığı, Gökler (2007) tarafından ise "Çocuklar İçin Sosyal Desteği Değerlendirme Ölçeği" yapı geçerlik ve güvenirlik çalışmasının yapıldığı ancak ölçeğin Ergen boyutunun ele alınmadığı belirlenmiştir. Bu nedenlerle ölçeğin özgün formu Türkçe'ye uyarlanarak geçerlik ve güvenirlik çalışması yapılmıştır.

Mc Whirter ve Mc Whirter (2008) tarafından geliştirilen 5'li Likert tipi "Ergenlerin gelecek beklentileri” ölçeği, Kesinlikle katılıyorum (5), Katılıyorum (4), Kararsızım (3), Katılmıyorum (2), Kesinlikle katılmıyorum (1) seçenekleri puanlanarak değerlendirilmiştir.

\section{Anket formunun uygulanması}

Araştırma verilerinin elde edilmesi amacıyla hazırlanan anket formları, 15 Mart 2010-10 Mayıs 2010 tarihleri arasında yüz yüze görüşme yapılarak uygulanmıştır. Ulaşılan ergen sayısının az olması nedeniyle anket formları 81 kişiye uygulanmıştır. Uygulanan anket formları değerlendirilerek geçerlilik ve güvenilirlik analizleri yapılmış, işleyen sorularla araştırmaya devam edilmiştir.

\section{Anket formuna geçerlik ve güvenirlik analizinin uygulanması}

Araştırmanın ilk aşamasında 81 ergene uygulanan anket formları değerlendirilerek yapı geçerlik ve güvenirlik testi yapılmıştır. Analiz sonucunda anket formunda aynı ve farklı yapıyı ölçen cümleler belirlenmiş, cümlelerin bir yapı altında yer alıp almadıkları ise madde faktör yük değeri ile incelenmiştir. Faktör analizinde yük değerlerinin 0.45 ve üstü olması önerilmekle birlikte uygulamada 0.30 yük değeri alt sınır olarak kabul edilmektedir (Köklü ve Büyüköztürk 2000, Büyüköztürk 2002). Bu çalışmada bir maddenin faktör yük değerinin 0.30 ve üstünde bulunması yeterli bulunmuştur. $\mathrm{Bu}$ değerin üstünde olan cümleler seçilmiş, bu değerin altında kalanlar ise anket formu kapsamı dışında bırakılmıştır. Anket formunun güvenirliliği için iç tutarlık katsayısı olan "Cronbach Alpha" hesaplanmıştır. Ayıca anket formunda yer alan soruların olumlu ve olumsuz tutumları ayıt etme gücü madde analizi yapılarak incelenmiştir. $\mathrm{Bu}$ amaçla madde puanları arasındaki korelasyonlar hesaplanmıştır. 
Tablo 1: Ergenlerin gelecek beklentilerine ilişkin faktör ve madde analizi sonuçları

\begin{tabular}{|c|c|c|}
\hline EĞiTiM, IŞ VE EKONOMIK DURUM & $\begin{array}{c}\text { Rotasyon sonrası faktördeki yük } \\
\text { değeri }\end{array}$ & Madde toplam korelasyonu \\
\hline 1. İstediğim eğitim düzeyine ulaşacağım. & .826 & .649 \\
\hline 2. Her zaman yeteri kadar karnımı doyuracak ve yaşayabileceğim. & .758 & .738 \\
\hline 3. Yaşamımda yapmak istediğim şeyleri başaracağım. & .799 & .782 \\
\hline 4. İstediklerime sahip olacağım. & .745 & .702 \\
\hline $\begin{array}{l}\text { 6. Sahip olacağım iş kendimle gurur duymam için bana firsatlar } \\
\text { sunacak. }\end{array}$ & .731 & .769 \\
\hline 7. lyi bir iş bulacağım. & .750 & .894 \\
\hline 8. İstikrarılı/sabit bir iş bulacağım. & .601 & .833 \\
\hline 9. Zevk aldığım bir iş bulacağım. & .798 & .807 \\
\hline Özdeğer: 5.425 & Açıklanan varyans: $\% 67.81$ & Alpha: 0.93 \\
\hline \multicolumn{3}{|l|}{ AILE YAŞAMI } \\
\hline 5. Eșimden alacağım para benim için yeterli olacak. & .539 & .493 \\
\hline 11. Evleneceğim. & .749 & .491 \\
\hline 13. Evililiğim sonsuza kadar sürecek. & .790 & .360 \\
\hline 14. Çocuklarım olacak. & .884 & .468 \\
\hline 15. Çocuklarıma yaşamaları için güvenli bir yer sağlayacağım. & .765 & .589 \\
\hline 16. Çocuklarım huzur içinde yaşayacaklar. & .782 & .659 \\
\hline 17. Çocuklarımın uzun bir yaşamı olacak. & .792 & .686 \\
\hline Özdeğer: 4.499 & Açıklanan varyans: \%64.77 & Alpha: 0.91 \\
\hline \multicolumn{3}{|l|}{ SOSYAL YAŞAM } \\
\hline 18. Sosyal grupların düzenlediği toplantılara katılacağım. & .323 & .590 \\
\hline $\begin{array}{l}\text { 19. Pek çok dini aktiviteye katılacağım, cami vb. ibadet yerlerine } \\
\text { gideceğim. }\end{array}$ & .732 & .392 \\
\hline 20. Kendi camiamda bir lider olacağım. & .657 & .550 \\
\hline Özdeğer: 1.795 & Açıklanan varyans: $\% 59.84$ & Alpha: 0.66 \\
\hline \multicolumn{3}{|l|}{ SAĞLIK } \\
\hline 10. Kendimden hoşnut olacağım. & .753 & .808 \\
\hline 21. Spor faaliyetlerine katılacağım. & .587 & .745 \\
\hline 22. Sağlıklı besleneceğim. & .796 & .812 \\
\hline 23. Sağııkı bir hayatım olacak. & .776 & .793 \\
\hline 24. Uzun bir yaşamım olacak. & .819 & .566 \\
\hline 25. Mutlu bir yaşamım olacak. & .764 & .612 \\
\hline Özdeğer: 4.385 & Açıklanan varyans: $\% 73.09$ & Alpha: 0.93 \\
\hline
\end{tabular}

"Gençlerin geleceklerine beklentileri" ölçeği için faktör analizi uygulanmıştır. Ölçek dört bölümden oluşmaktadır. Gençlerin "Eğitim, iş ve ekonomik durumları"na ilişkin bölümün faktör yük değerleri 0.60 ile 0.83 , madde toplam korelasyonları 0.65 ile 0.83 arasında değişmektedir. Ölçeğin güvenilirliği için hesaplanan alpha 0.93 , açıklanan varyans \%67.81'dir. İkinci bölüm olan "aile yaşamı"na ilişkin faktör yük değerlerinin 0.54 ile 0.89 , madde toplam korelasyonlarının 0.36 ile 0.69 arasında değiştiği saptanmıştır. Güvenilirlik için hesaplanan Alpha 0.91, açıklanan varyans \%64.77'dir. Gençlerin gelecek beklentileri ölçeğinde yer alan "sosyal yaşam" alt ölçeğindeki maddelerin faktör yük değerleri 0.32 ile 0.73 , madde toplam korelasyonları 0.39 ile 0.59 arasındadır. Ölçeğin güvenilirliği için hesaplanan Alpha değeri 0.66, açıklanan varyans \%59.84'tür. Son bölüm olan "sağlık" başlığıyla ilgili bulunan faktör yük değerleri 0.587 ile 0.819 , madde toplam korelasyonları 0.0 .566 ile 0.808 arasında olduğu görülmüştür. Araştırma için kullanılan ölçeğin güvenilirliği 
için hesaplanan Alpha değeri 0.93, açıklanan varyans \%73.09 olarak bulunmuştur (Tablo 1).
Gençlerin sosyal destek algılarına ilişkin faktör ve madde analizi ise aile, öğretmen, yakın arkadaşları ile sınıf arkadaşlarını içeren 4 bölümde değerlendirilmiştir.

Tablo 2: Ergenlerin sosyal destek algılarına ilişkin faktör ve madde analizi sonuçları

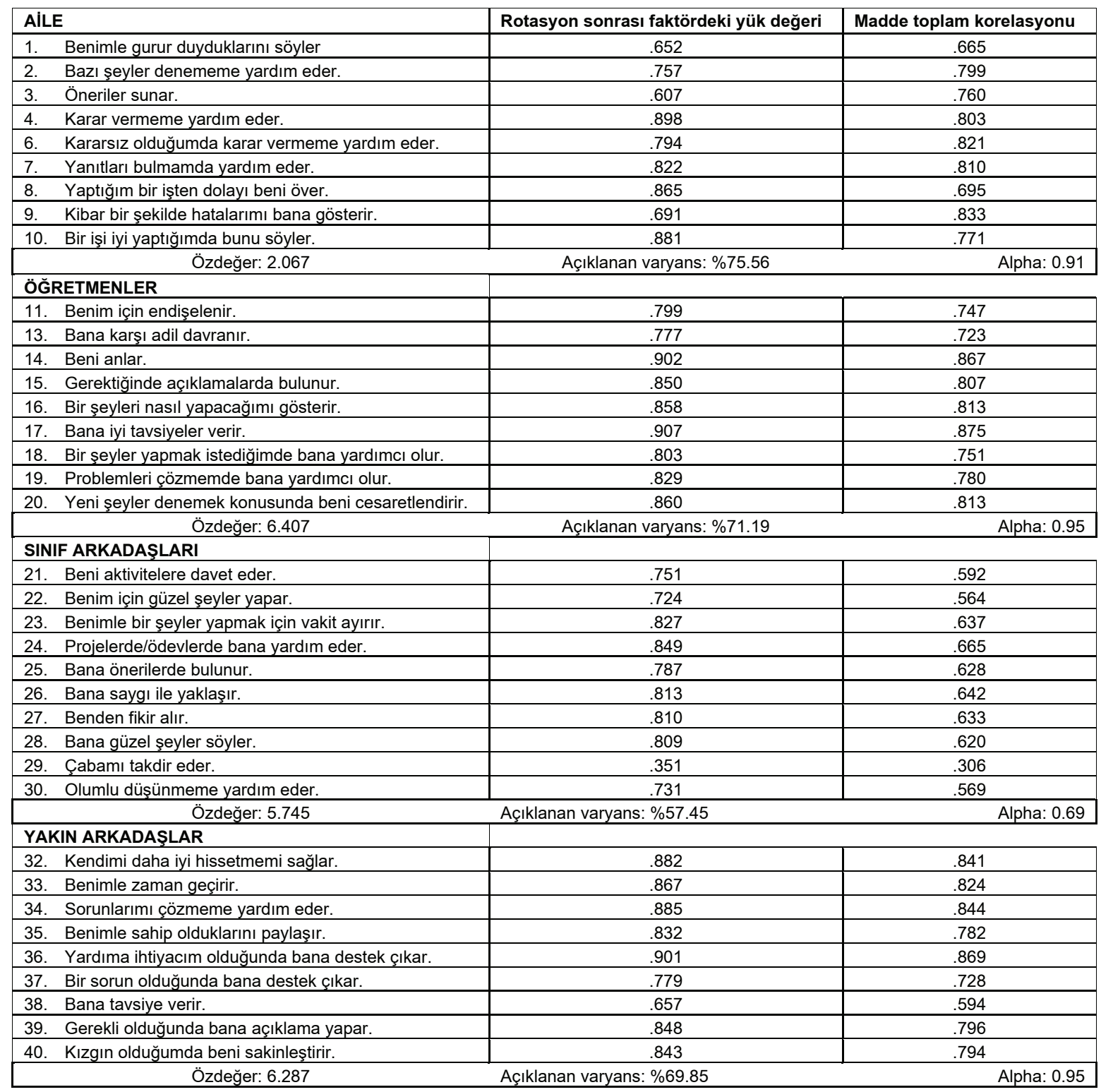

* Faktör yük değeri 0.30'un altında olduğu için anket formundan çıkarılmıştır ( 5.Bana iyi tavsiyeler verir, 12. Bana önem verir, 31. Benim duygularımı anlar). 
Gençlerin sosyal destek algılarını belirlemek amacıyla geliştirilen ölçeğin faktör ve madde analizi sonuçları incelendiğinde, 'aile' bölümünde değerlendirmeye alınan 5 . maddenin faktör yük değerinin 0.30 'un altında olduğu belirlenmiştir. $\mathrm{Bu}$ madde dahil edilmeden yinelenen faktör ve madde analiz sonuçlarına göre geriye kalan diğer 9 maddenin faktör yük değerleri 0.61 ile 0.89 , madde toplam korelasyonlarının da 0.67 ile 0.83 arasında bulunmaktadır. Güvenilirlik için hesaplanan Alpha 0.91, açıklanan varyans $\% 75.56$ 'dır.

Gençlerin sosyal destek algılarını ölçmek için "öğretmen" başlığı altında değerlendirme kapsamına alınan 10 maddeden 12. maddenin faktör yük değerinin 0.30 'un altında çıkması nedeniyle çıkarılmıştır. Bu madde çıkarıldıktan sonra tekrar yapılan faktör ve madde analiz sonuçları diğer 9 madde için faktör yük değerlerinin 0.78 ile 0.90 , madde toplam korelasyonlarının 0.72 ile 0.88 arasında bulunduğunu, Alpha değerinin 0.95 ve açıklanan varyansın \%71.19 olduğunu göstermektedir.

"Sınıf arkadaşları" bölümünde gençlerin sosyal destek algıları üzerindeki etkilerini ölçmek için değerlendirmeye alınan 10 maddenin faktör ve madde analiz sonuçlarına bakıldığında, faktör yük değerlerinin 0.35 ile 0.85 , madde toplam korelasyonlarının 0.31 ile 0.67 arasında olduğu, güvenirlik için hesaplanan Alpha değerinin 0.69 ve açıklanan varyansın $\% 57.45$ olduğu belirlenmiştir.

Gençlerin sosyal destek algılarına ilişkin beklentileri ile ilgili son bölüm "yakın arkadaşlar"dır. Bu bölümde 10 madde değerlendirmeye alınmıştır. 31. maddenin faktör yük değeri 0.30 'un altında bulunduğundan bu madde ölçek kapsamından çıkarılmışır. Bu madde çıkarıldıktan sonra yinelenen faktör ve madde analiz sonuçlarına göre geriye kalan diğer maddelerin faktör yük değerleri 0.66 ile 0.90 , madde toplam korelasyonları 0.59 ile 0.87 arasında değişmektedir. Ölçeğin güvenilirliğini ölçen alpha değeri 0.95 , açıklanan varyans $\% 69.85$ olarak bulunmuştur (Tablo 2).

\section{Verilerin değerlendirilmesi}

Araştırma sonucunda elde edilen bilgiler bulgular SPSS 16.0 paket yazılım programından yararlanılarak oluşturulan veri tabanında toplanmıştır. Bu yazılımdan faydalanarak bilgilerin sınıflandırılması ve boyutlandırıması gerçekleştirilmiştir. Ergenlere ilişkin sosyo-demografik bulgular bölümünde yer alan sorular için mutlak ve yüzde değerler hesaplanmış, gerekli aritmetik ortalamalar alınmıştır. Ergenlerin sosyal destek algıları ve gelecek beklentileri ölçeklerinde yer alan her madde için gerekli aritmetik ortalamalar hesaplanmış, cinsiyet değişkenine bağlı olarak t-testi uygulanmıştır. Ayrıca Ergenlerin "Ergenlerin gelecek beklentileri" ölçeğinde yer alan "eğitim, iş ve ekonomik durum", "aile yaşamı", "sosyal yaşam", "sağlık" alt ölçeklerinden ve "Sosyal destek algıları" ölçeğinde yer alan "aile", "öğretmenler", "sınıf arkadaşları" ve "yakın arkadaşlar" alt ölçeklerinden aldıkları toplam puanlar hesaplanmış, toplam puanlara ilişkin gerekli aritmetik ortalamalar alındıktan sonra cinsiyet değişkenine bağlı farklıı̆ı̆ı ölçülebilmesi için ttesti uygulanmıştır.

\section{Bulgular}

$\mathrm{Bu}$ kısımda; ergenlere ilişkin sosyodemografik bulgular, gençlerin gelecek beklentileri başlıkları ele alınmıştır. Bu başlıklar altında da gençlerin eğitim, iş ve ekonomik durumları; aile yaşamları, sosyal yaşamları, sağlık durumları, gençlerin aile, öğretmen, yakın arkadaş çevresi ve sınıf arkadaşlarından algıladıkları sosyal destek gibi konulara da ayrıntılı bir şekilde değinilmiştir.

\section{Bulgular \\ Ergenlere İlişkin Sosyo-Demografik}

Araştırmaya katılan ergenlerin demografik bilgileri Tablo 3'de gösterilmiştir. 
Tablo 3: Gençlere Illişkin demografik bulgular

\begin{tabular}{|c|c|c|c|}
\hline & & Sayı & $\%$ \\
\hline \multirow[t]{3}{*}{ Kurum } & Atatürk Kız Yetiştirme Yurdu & 51 & 63.0 \\
\hline & Gazi Yetiştirme Yurdu & 30 & 37.0 \\
\hline & Toplam & 81 & 100.0 \\
\hline \multirow[t]{3}{*}{ Cinsiyet } & $\mathrm{KIZ}$ & 51 & 63.0 \\
\hline & Erkek & 30 & 37.0 \\
\hline & Toplam & 81 & 100.0 \\
\hline \multirow[t]{3}{*}{ Yaş } & $12-15$ & 38 & 46.9 \\
\hline & $16-19$ & 43 & 53.1 \\
\hline & Toplam & 81 & 100.0 \\
\hline \multirow[t]{9}{*}{ Sinıf } & Okula gitmiyor & 7 & 8.6 \\
\hline & 6. Sinıf & 9 & 11.1 \\
\hline & 7. SInIf & 12 & 14.8 \\
\hline & 8. $\quad$ Sinıf & 13 & 16.0 \\
\hline & 9. Sinıf & 18 & 22.2 \\
\hline & 10. SInIf & 16 & 19.8 \\
\hline & 11. Sinıf & 4 & 4.9 \\
\hline & 12. SInIf & 2 & 2.5 \\
\hline & Toplam & 81 & 100.0 \\
\hline \multirow[t]{4}{*}{ Aile } & Hayatta & 67 & 82.7 \\
\hline & Hayatta değil & 10 & 12.3 \\
\hline & Bilmiyor-terk & 4 & 4.9 \\
\hline & Toplam & 81 & 100.0 \\
\hline \multirow[t]{7}{*}{ Ailesi ile görüşme sıklığı } & Haftada bir kez & 17 & 21.0 \\
\hline & 2 haftada bir kez & 7 & 8.6 \\
\hline & Ayda bir kez & 6 & 7.4 \\
\hline & Yılda birkaç kez & 14 & 17.3 \\
\hline & Görüşmüyor & 21 & 25.9 \\
\hline & Diğer & 16 & 19.8 \\
\hline & Toplam & 81 & 100.0 \\
\hline \multirow[t]{3}{*}{ Koruyucu Aile Hizmeti } & Yararlanıyor & 6 & 7.4 \\
\hline & Yararlanmıyor & 75 & 92.6 \\
\hline & Toplam & 81 & 100.0 \\
\hline
\end{tabular}

Tablo 3'te de görüldüğü gibi, araştırma kapsamına alınan ergenlerin \%63.0'ı kız \%37.0'ı erkektir. Yaşları 13-19 arasında değişmekte olup, \%46.9'u 12-15, \%53.1' ise 16-19 yaş grubundadır. Ergenlerin öğrenim durumları incelendiğinde \%91.4'nün okula devam ettiği, geriye kalan \%8.6'ık kısım ise okula devam etmediği görülmektedir. Tablo 3'ten de anlaşılacağı gibi çalışmaya alınan ergenlerin aile durumlarına bakıldığında, $\% 82.7$ 'sinin ailesi hayatta olup, \%12.3'nün ailesini kaybettiği ve geriye kalan \%4.9'nun da ailesine ilişkin net bir bilgiye sahip olmadıkları görülmüştür. Araştırmaya katılan ergenlerin aileleri ile görüşme sıklığı incelendiğinde \%21.0'ının haftada bir, \%8.6'sının haftada iki, \%7.4'nün ayda bir ve \%17.3'nün de yılda birkaç kez aileleri ile görüştüğü saptanmıştır. Buna karşılık \%25.9'u ailesi ile görüşmemekte ve \%19.8'sinin ise ne kadar sıklıkla görüştüğüne dair net bir bilgi elde edilmemiştir. Yurtta kalan ergenlerin \%7.4'ünün koruyucu aile hizmetinden yararlandığı, buna karşılık \%92.6'sının bu hizmetten yararlanmadığı belirlenmiştir (Tablo 3).

\section{Ergenlerin Gelecek Beklentileri}

Ergenlerin geleceğe ilişkin beklentileri; iş ve ekonomik durumlarına, aile yaşamlarına, sosyal yaşamlarına, sağlık durumlarına ilişkin gelecek beklentileri başlıkları altında ele alınmıştır.

\section{Ergenlerin eğitim, iş ve ekonomik} durumlarına ilişkin gelecek beklentileri

Çalışma kapsamına alınan korunmaya muhtaç ergenlerin; eğitim, iş ve ekonomik durumlarına ilişkin gelecek beklentileri Tablo 4'de verilmiştir. 
Tablo 4: Cinsiyete göre ergenlerin gelecek beklentileri ve t testi sonuçları

\begin{tabular}{|c|c|c|c|c|c|c|c|c|c|c|c|}
\hline & \multicolumn{3}{|c|}{ Kız } & \multicolumn{3}{|c|}{ Erkek } & \multicolumn{3}{|c|}{ Toplam } & \multirow[t]{2}{*}{$\mathbf{t}$} \\
\hline & & $\mathbf{N}$ & $\overline{\mathrm{x}}$ & $\mathbf{s}$ & $\mathbf{N}$ & $\bar{x}$ & $\mathbf{s}$ & $\mathbf{n}$ & $\bar{x}$ & $s$ & \\
\hline \multirow{8}{*}{$\begin{array}{l}\text { EĞiTiM, İş } \\
\text { VE } \\
\text { EKONOMIK } \\
\text { DURUM }\end{array}$} & $\begin{array}{l}\text { 1. İstediğim eğitim düzeyine } \\
\text { ulaşacağım. }\end{array}$ & 51 & 3.39 & 1.47 & 30 & 3.10 & 1.39 & 81 & 3.28 & 1.44 & .879 \\
\hline & $\begin{array}{l}\text { 2. Her zaman yeteri kadar } \\
\text { karnımı doyuracak ve } \\
\text { yaşayabileceğim. }\end{array}$ & 51 & 3.51 & 1.35 & 30 & 3.07 & 1.39 & 81 & 3.35 & 1.37 & 1.414 \\
\hline & $\begin{array}{l}\text { 3. Yaşamımda yapmak istediğim } \\
\text { şeyleri başaracağım. }\end{array}$ & 51 & 3.59 & 1.17 & 30 & 3.33 & 1.18 & 81 & 3.49 & 1.17 & .943 \\
\hline & 4. İstediklerime sahip olacağım. & 51 & 3.45 & 1.17 & 30 & 3.03 & 1.13 & 81 & 3.29 & 1.17 & 1.570 \\
\hline & $\begin{array}{l}\text { 6. Sahip olacağım iş kendimle } \\
\text { gurur duymam için bana fırsatlar } \\
\text { sunacak. }\end{array}$ & 51 & 3.31 & 1.38 & 30 & 3.13 & 136 & 81 & 3.25 & 1.37 & .572 \\
\hline & 7. İyi bir iş bulacağım. & 51 & 3.31 & 1.36 & 30 & 3.17 & 1.29 & 81 & 3.26 & 1.33 & .478 \\
\hline & 8. İstikrarlı/sabit bir iş bulacağım. & 51 & 3.27 & 1.42 & 30 & 3.13 & 1.19 & 81 & 3.22 & 1.33 & .548 \\
\hline & 9. Zevk aldığım bir iş bulacağım. & 51 & 3.63 & 1.42 & 30 & 3.06 & 1.23 & 81 & 3.41 & 1.37 & 1.794 \\
\hline \multirow{7}{*}{$\begin{array}{l}\text { AiLE } \\
\text { YAŞAMI }\end{array}$} & $\begin{array}{l}\text { 5. Eşimden alacağım para benim } \\
\text { için yeterli olacak. }\end{array}$ & 51 & 3.18 & 1.12 & 30 & 3.27 & 1.20 & 81 & 3.21 & 1.15 & .340 \\
\hline & 11. Evleneceğim. & 51 & 2.88 & 1.14 & 30 & 3.30 & 1.21 & 81 & 3.03 & 1.17 & 1.555 \\
\hline & $\begin{array}{l}\text { 13. Evliliğim sonsuza kadar } \\
\text { sürecek. }\end{array}$ & 51 & 2.98 & 1.24 & 30 & 3.03 & 1.27 & 81 & 3.00 & 1.24 & .184 \\
\hline & 14. Çocuklarım olacak. & 51 & 3.13 & 3.13 & 30 & 3.10 & 1.16 & 81 & 3.12 & 1.13 & .142 \\
\hline & $\begin{array}{l}\text { 15. Çocuklarıma yaşamaları için } \\
\text { güvenli bir yer sağlayacağım. }\end{array}$ & 51 & 3.49 & 1.25 & 30 & 3.36 & 1.49 & 81 & 3.44 & 1.34 & .398 \\
\hline & $\begin{array}{l}\text { 16. Çocuklarım huzur içinde } \\
\text { yaşayacaklar. }\end{array}$ & 51 & 3.35 & 1.44 & 30 & 3.50 & 1.28 & 81 & 3.40 & 1.38 & .462 \\
\hline & $\begin{array}{l}\text { 17. Çocuklarımın uzun bir yaşamı } \\
\text { olacak. }\end{array}$ & 51 & 3.22 & 1.32 & 30 & 3.23 & 1.43 & 81 & 3.22 & 1.35 & .056 \\
\hline \multirow{3}{*}{$\begin{array}{l}\text { SOSYAL } \\
\text { YAŞAM }\end{array}$} & $\begin{array}{l}\text { 18. Sosyal grupların düzenlediği } \\
\text { toplantılara katılacağım. }\end{array}$ & 51 & 3.12 & 1.42 & 30 & 3.47 & 1.22 & 81 & 3.24 & 1.36 & 1.121 \\
\hline & $\begin{array}{l}\text { 19. Pek çok dini aktiviteye } \\
\text { katılacağım. cami vb. ibadet } \\
\text { yerlerine gideceğim. }\end{array}$ & 51 & 3.45 & 1.25 & 30 & 3.43 & 1.19 & 81 & 3.44 & 1.22 & .062 \\
\hline & $\begin{array}{l}\text { 20. Kendi camiamda bir lider } \\
\text { olacağım. }\end{array}$ & 51 & 3.19 & 1.27 & 30 & 3.33 & 1.39 & 81 & 3.25 & 1.31 & .453 \\
\hline \multirow{6}{*}{ SAĞLIK } & 10. Kendimden hoşnut olacağım. & 51 & 3.33 & 1.43 & 30 & 3.47 & 1.25 & 81 & 3.38 & 1.37 & .422 \\
\hline & $\begin{array}{l}\text { 21. Spor faaliyetlerine } \\
\text { katılacağım. }\end{array}$ & 51 & 3.47 & 1.40 & 30 & 3.60 & 1.32 & 81 & 3.52 & 1.37 & .408 \\
\hline & 22. Sağlıklı besleneceğim. & 51 & 3.41 & 1.49 & 30 & 3.47 & 1.36 & 81 & 3.43 & 1.44 & .165 \\
\hline & 23. Sağlıklı bir hayatım olacak. & 51 & 3.33 & 1.45 & 30 & 3.37 & 1.33 & 81 & 3.35 & 1.40 & .103 \\
\hline & 24. Uzun bir yaşamım olacak. & 51 & 3.39 & 1.29 & 30 & 3.47 & 1.38 & 81 & 3.42 & 1.32 & .244 \\
\hline & 25. Mutlu bir yaşamım olacak. & 51 & 3.39 & 1.32 & 30 & 3.43 & 1.43 & 81 & 3.40 & 1.36 & .131 \\
\hline
\end{tabular}


Tablo 5: Cinsiyete göre ergenlerin sosyal destek algıları ve t testi sonuçları

\begin{tabular}{|c|c|c|c|c|c|c|c|c|c|c|c|}
\hline & \multicolumn{3}{|c|}{ Kız } & \multirow{2}{*}{$\begin{array}{c}\text { Erkek } \\
\mathrm{n}\end{array}$} & \multicolumn{5}{|c|}{ Toplam } & \multirow[b]{2}{*}{$\mathbf{t}$} \\
\hline & & $\mathbf{n}$ & $\bar{x}$ & $\mathbf{s}$ & & $\bar{x}$ & $\mathbf{s}$ & n & $\bar{x}$ & $\mathbf{s}$ & \\
\hline \multirow{9}{*}{ AilLE } & 1. Benimle gurur duyduklarını söyler & 51 & 1.82 & 1.01 & 30 & 1.87 & .94 & 81 & 1.84 & 0.98 & .190 \\
\hline & 2. Bazı şeyler denememe yardım eder. & 51 & 1.75 & .87 & 30 & 1.67 & .96 & 81 & 1.72 & .89 & .378 \\
\hline & 3. Öneriler sunar. & 51 & 1.80 & .94 & 30 & 1.73 & .98 & 81 & 1.77 & .95 & .322 \\
\hline & 4. Karar vermeme yardım eder. & 51 & 1.76 & 1.07 & 30 & 1.73 & .98 & 81 & 1.75 & 1.03 & .131 \\
\hline & $\begin{array}{l}\text { 6. Kararsız olduğumda karar vermeme } \\
\text { yardım eder. }\end{array}$ & 51 & 1.75 & 1.02 & 30 & 1.60 & 1.07 & 81 & 1.70 & 1.03 & .608 \\
\hline & 7. Yanıtları bulmamda yardım eder. & 51 & 1.90 & 1.02 & 30 & 1.63 & .93 & 81 & 1.80 & .99 & 1.179 \\
\hline & 8. Yaptığım bir işten dolayı beni över. & 51 & 1.67 & 1.10 & 30 & 1.90 & .95 & 81 & 1.76 & 1.06 & .961 \\
\hline & $\begin{array}{l}\text { 9. Kibar bir şekilde hatalarımı bana } \\
\text { gösterir. }\end{array}$ & 51 & 1.67 & 1.06 & 30 & 1.90 & 1.03 & 81 & 1.72 & 1.04 & .555 \\
\hline & 10. Bir işi iyi yaptı̆̆ımda bunu söyler. & 51 & 1.84 & 1.03 & 30 & 1.93 & 1.01 & 81 & 1.88 & 1.02 & .383 \\
\hline \multirow{9}{*}{ ÖĞRETMENLER } & 11.Benim için endişelenir. & 51 & 2.06 & .93 & 30 & 1.63 & 1.13 & 81 & 1.90 & 1.02 & 1.840 \\
\hline & 12.Bana önem verir. & 51 & 2.16 & .86 & 30 & 1.93 & 2.02 & 81 & 2.07 & 1.39 & .694 \\
\hline & 13.Bana karşı adil davranır. & 51 & 2.06 & .99 & 30 & 1.80 & 1.21 & 81 & 1.96 & 1.08 & 1.045 \\
\hline & 14.Beni anlar. & 51 & 2.18 & .84 & 30 & 1.57 & 1.14 & 81 & 1.95 & .99 & $2.761^{* \star}$ \\
\hline & 15.Gerektiğinde açıklamalarda bulunur. & 51 & 2.12 & .86 & 30 & 1.60 & 1.16 & 81 & 1.93 & 1.01 & $2.286^{*}$ \\
\hline & 16.Bir şeyleri nasıl yapacağımı gösterir. & 51 & 2.08 & .91 & 30 & 1.67 & 1.12 & 81 & 1.93 & 1.01 & 1.797 \\
\hline & 17.Bana iyi tavsiyeler verir. & 51 & 2.10 & .90 & 30 & 1.70 & 1.15 & 81 & 1.95 & 1.01 & 1.732 \\
\hline & $\begin{array}{l}\text { 18.Bir şeyler yapmak istediğimde bana } \\
\text { yardımcı olur. }\end{array}$ & 51 & 2.04 & .98 & 30 & 1.67 & 1.10 & 81 & 1.90 & 1.03 & 1.584 \\
\hline & $\begin{array}{l}\text { 19.Problemleri çözmemde bana } \\
\text { yardımcı olur. }\end{array}$ & 51 & 2.04 & .89 & 30 & 1.87 & 1.20 & 81 & 1.98 & 1.01 & .739 \\
\hline \multirow{10}{*}{$\begin{array}{c}\text { SINIF } \\
\text { ARKADAŞLARI }\end{array}$} & 21.Beni aktivitelere davet eder. & 51 & 1.60 & 1.06 & 30 & 1.70 & 1.15 & 81 & 1.64 & 1.09 & .366 \\
\hline & 22.Benim için güzel şeyler yapar. & 51 & 1.86 & 1.06 & 30 & 1.50 & 1.17 & 81 & 1.73 & 1.11 & 1.434 \\
\hline & $\begin{array}{l}\text { 23.Benimle bir şeyler yapmak için vakit } \\
\text { ayıır. }\end{array}$ & 51 & 1.88 & 1.11 & 30 & 1.63 & 1.22 & 81 & 1.79 & 1.15 & .942 \\
\hline & $\begin{array}{l}\text { 24.Projelerde/ödevlerde bana yardım } \\
\text { eder. }\end{array}$ & 51 & 1.78 & 1.03 & 30 & 1.47 & 1.14 & 81 & 1.67 & 1.07 & 1.293 \\
\hline & 25.Bana önerilerde bulunur. & 51 & 1.67 & 1.05 & 30 & 1.27 & 1.14 & 81 & 1.52 & 1.10 & 1.601 \\
\hline & 26.Bana saygı ile yaklaşır. & 51 & 1.88 & 1.05 & 30 & 1.67 & 1.18 & 81 & 1.80 & 1.10 & .851 \\
\hline & 27.Benden fikir alır. & 51 & 1.88 & 1.07 & 30 & 1.57 & 1.25 & 81 & 1.77 & 1.14 & 1.204 \\
\hline & 28.Bana güzel şeyler söyler. & 51 & 1.88 & 1.13 & 30 & 1.50 & 1.14 & 81 & 1.74 & 1.14 & 1.471 \\
\hline & 29.Bana saygı ile yaklaşır. & 51 & 2.37 & 4.49 & 30 & 1.63 & 1.13 & 81 & 2.10 & 3.64 & .883 \\
\hline & 30.Olumlu düşünmeme yardım eder. & 51 & 1.94 & 1.10 & 30 & 1.57 & 1.14 & 81 & 1.80 & 1.12 & 1.460 \\
\hline \multirow{9}{*}{$\begin{array}{c}\text { YAKIN } \\
\text { ARKADAŞLAR }\end{array}$} & 31.Benim duygularımı anlar. & 51 & 2.61 & 4.46 & 30 & 1.77 & 1.14 & 81 & 2.30 & 3.61 & 1.012 \\
\hline & 32.Kendimi daha iyi hissetmemi sağlar. & 51 & 1.96 & 1.13 & 30 & 1.60 & 1.22 & 81 & 1.83 & 1.17 & 1.347 \\
\hline & 33.Benimle zaman geçirir. & 51 & 2.10 & 1.04 & 30 & 1.83 & 1.15 & 81 & 2.00 & 1.08 & 1.062 \\
\hline & 34.Sorunlarımı çözmeme yardım eder. & 51 & 2.08 & 1.07 & 30 & 1.80 & 1.10 & 81 & 1.97 & 1.08 & 1.118 \\
\hline & 35.Benimle sahip olduklarını paylaşır. & 51 & 2.06 & 1.07 & 30 & 1.47 & 1.20 & 81 & 1.84 & 1.15 & .531 \\
\hline & $\begin{array}{l}\text { 36.Yardıma intiyacım olduğunda bana } \\
\text { destek olur. }\end{array}$ & 51 & 2.06 & 1.07 & 30 & 1.47 & 1.20 & 81 & 1.84 & 1.15 & $2.307^{*}$ \\
\hline & $\begin{array}{l}\text { 37.Bir sorun olduğunda bana destek } \\
\text { çıkar. }\end{array}$ & 51 & 2.18 & 1.09 & 30 & 1.63 & 1.10 & 81 & 1.98 & 1.12 & 2.160 \\
\hline & 38.Bana tavsiye verir. & 51 & 1.98 & 1.01 & 30 & 1.73 & 1.23 & 81 & 1.89 & 1.10 & .980 \\
\hline & $\begin{array}{l}\text { 39.Gerekli olduğunda bana açıklama } \\
\text { yapar. }\end{array}$ & 51 & 2.04 & 1.09 & 30 & 1.83 & 1.15 & 81 & 1.96 & 1.11 & .803 \\
\hline
\end{tabular}


Ergenlerin eğitim, iş ve ekonomik durumları alt ölçeğinde yer alan cümleler incelendiğinde; "Yaşamımda yapmak istediğim şeyleri başaracağım" ( $\bar{X}=3.49)$, "Zevk aldığım bir iş bulacağım" ( $\bar{X}=3.41)$, "Her zaman yeteri kadarına sahip olacağım" $(\bar{X}=3.35)$ cümlelerine daha çok katıldıklarını, yani yaşamlarında zevk aldıkları bir şeyleri yapma, iş bulma her zaman yeteri kadarına sahip olma konusunda daha yüksek beklentileri olduğu; bu konularda kızların eğitim, iş ve ekonomik konularla ilgili beklentilerinin erkeklerin beklentilerinden yüksek olduğu, ancak kız ve erkek ergenler arasında istatistiksel olarak anlamlı bir farklılık bulunmadığı belirlenmiştir $(p>0.05)$ (Tablo 4).

Ergenlerin aile yaşamına ilişkin beklentileri incelendiğinde; en çok çocuklarına yaşamaları için güvenli bir yer sağlama ile ilgili beklentileri olduğu $(\bar{x}=3.44)$ bunu sırası ile "Çocuklarım huzur içinde yaşayacak" ( $\bar{X}=$ 3.40), "Çocuklarımın uzun bir yaşamı olacak" $(\bar{X}=3.22)$ cümlelerinin takip ettiği bulunmuştur. Ergenlerin evlilik ve eş ile ilgili beklentileri konusunda ise çoğunlukla kararsız oldukları gözlenmiştir. Cinsiyet değişkenine bağlı farklılığı belirlemek için yapılan $t$ - testi sonuçları, cinsiyete bağlı farklııı bulunmadığını göstermiştir ( $p>0.05$ ) (Tablo 4).

Sosyal yaşama ilişkin beklentiler ile ilgili olarak ergenlerin en çok "Pek çok dini aktiviteye katılacağım, cami vb. ibadet evlerine gideceğim" cümlesine katıldıkları saptanmış; sosyal yaşama ilişkin beklentilerinde farklılık bulunmamıştır ( $p>0.05$ ) (Tablo 4$)$.

Gençlerin ilerideki sağlık durumlarına ilişkin beklentilerinin "Spor faaliyetlerine katılma", "Sağlıklı beslenme", "Uzun bir yaşama sahip olma" konularında daha yüksek olduğu saptanmıştır. Erkeklerin sağlık durumlarına ilişkin beklentileri kızların beklentilerinden biraz daha yüksek olmakla birlikte ortalamalara ilişkin farklııklar istatistiksel açıdan anlamlı değildir $(p>0.05)$ (Tablo 4).

\section{Ergenlerin algıladıkları sosyal destek}

Tablo 5'de çalışma kapsamına alınan korunmaya muhtaç ergenlerin sosyal destek algıları yer almaktadır.

Tablo 5: Cinsiyete göre ergenlerin sosyal destek algıları ve t testi sonuçları

Ergenlerin aile yaşamlarına ilişkin sosyal destek algıları en çok "Bir işi yaptığımda bunu söyler" ( $\bar{X}=1.88)$, "Benimle gurur duyduklarını söyler" ( $\bar{X}=1.84)$ ve "Yanıtları bulmamda yardım eder" ( $\bar{X}=1.80)$ cümlelerinde yüksek olduğu; genel olarak erkeklerin ailelerinden algıladıkları sosyal desteğin kızların sosyal destek algılarından yüksek olduğu saptanmıştır $(p>0.05)$ (Tablo 5).

Ergenlerin öğretmenlerinden algıladıkları sosyal destek en çok kendilerine önem verildiği $(\bar{X}=2.07)$ ve adil davranıldığı $(\bar{X}=1.96)$ konularında olduğu görülmüştür. Kız ergenler öğretmenlerinin kendilerini anladığını erkek ergenlerden daha çok düşünmektedir ( $\bar{X}=$ 2.18, $\bar{x}=1.57$ ). Yapılan istatistik analiz sonuçları kız ve erkeklerin öğretmenlerinin kendilerini anladığını düşünme durumlarının farklılaştığını göstermiştir $\quad(p<0.01)$. "Gerektiğinde açıklamalarda bulunur" cümlesine ilişkin ortalama puanlarda cinsiyet değişkenine göre değişirken, kız ergenlerin ortalaması erkek ergenlerin otalamasından yüksektir $(\bar{X}=2.12, \bar{x}=1.16)(p<0.05)(T a b l o$ 5).

Ergenlerin sınıf arkadaşlarına ilişkin sosyal destek algıları ile ilgili cümlelerden en çok sınıf arkadaşlarının çabalarını takdir ettikleri $(\bar{x}=2.14)$, kendilerine saygı ile yaklaştıkları $(\bar{X}=1.80)$ ve sınıf arkadaşlarının olumlu düşünmelerine yardımcı olduklarına $(\bar{X}=1.80)$ ilişsin olumlu algıları olduğu; kızların 
sınıf arkadaşlarından algıladıkları sosyal desteğin erkeklerin algısından daha yüksek olduğu ancak farklılığın istatistiksel anlamlı bulunmadığı görülmüştür ( $p>0.05)$ (Tablo 5).

Ergenler yakın arkadaşları ile ilgili olarak en çok yakın arkadaşlarının kendi duygularını anladığını ( $\bar{X}=2.30$ ), onlarla zaman geçirdiğini $(\bar{X}=2.00)$ ve bir sorun olduğunda kendilerine destek olduklarını düşünmektedirler ( $\bar{X}=1.98)$. Yakın arkadaşları ile ilgili olarak algılanan soysal desteğin genel olarak kız ergenlerde erkeklerden yüksek olduğu, ancak "yardıma intiyacım olduğunda bana destek olur" ( $\bar{x}=$ 2.06, $\bar{x}=1.47)(p<0.05)$ ifadesi dışında tüm cümlelerde cinsiyete bağlı farklılık gözlenmediği saptanmıştır ( $p>0.05)$ (Tablo 5).

Tablo 6: Gençlerin gelecek beklentileri ile cinsiyet arasındaki farklıık ve t testi sonuçları

\begin{tabular}{|l|c|c|c|c|c|c|c|c|c|c|}
\hline \multirow{2}{*}{$\begin{array}{l}\text { ERGENLERIN GELECEK } \\
\text { BEKLENTiLERI }\end{array}$} & $\mathbf{n}$ & $\overline{\mathbf{X}}$ & $\mathbf{S}$ & $\mathbf{n}$ & $\overline{\mathbf{X}}$ & $\mathbf{S}$ & $\mathbf{n}$ & $\overline{\mathbf{X}}$ & $\mathbf{S}$ & $\mathbf{t}$ \\
\cline { 2 - 11 } & & & & & & & & \\
\hline Eğitim, iş ve ekonomik durum & 51 & 27.47 & 9.15 & 30 & 25.03 & 7.43 & 81 & 26.57 & 8.59 & 1.238 \\
\hline Aile Yaşamı & 51 & 22.24 & 6.68 & 30 & 22.80 & 7.17 & 81 & 22.44 & 6.82 & .358 \\
\hline Sosyal Yaşam & 51 & 9.76 & 3.03 & 30 & 10.23 & 3.00 & 81 & 9.94 & 3.01 & .674 \\
\hline Sağlık & 51 & 20.33 & 7.33 & 30 & 20.80 & 6.28 & 81 & 20.51 & 6.92 & .291 \\
\hline Toplam & 51 & 82.41 & 22.94 & 30 & 81.87 & 19.03 & 81 & 82.21 & 21.46 & .110 \\
\hline
\end{tabular}

Ergenlerin gelecek beklentilerine ilişkin genel bulgular ergenlerin beklentilerinin en çok eğitim, iş ve ekonomik konularla ilişkili olduğunu, bunu sırası ile aile yaşamı ve sağlık ilgili gelecek beklentilerinin izlediği saptanmıştır. Tablodan da izlenebileceği gibi ergenlerin gelecekte sosyal yaşama ilişkin neredeyse herhangi bir beklentisi bulunmamaktadır ( $p>0.05$ ) (Tablo 6).

Tablo 7: Gençlerin sosyal destek algıları ile cinsiyet arasındaki farklılık ve t testi sonuçları

\begin{tabular}{|l|c|c|c|c|c|c|c|c|c|c|c|}
\hline ERGENLERIN SOSYAL DESTEK & \multicolumn{4}{|c|}{ Kız } & \multicolumn{3}{|c|}{ Erkek } & \multicolumn{3}{|c|}{ Toplam } & \multicolumn{1}{|c|}{$\mathbf{T}$} \\
\cline { 2 - 11 } ALGILARI & $\mathbf{N}$ & $\overline{\mathbf{X}}$ & $\mathbf{S}$ & $\mathbf{n}$ & $\overline{\mathbf{X}}$ & $\mathbf{S}$ & $\mathbf{n}$ & $\overline{\mathbf{X}}$ & $\mathbf{S}$ & $\mathbf{2}$ \\
\hline Aile & 51 & 17.98 & 8.75 & 30 & 17.47 & 6.36 & 81 & 17.79 & 7.91 & .281 \\
\hline Öğretmenler & 51 & 20.88 & 7.60 & 30 & 17.23 & 8.81 & 81 & 19.53 & 8.21 & $1.966^{*}$ \\
\hline Sınıf Arkadaşları & 51 & 18.76 & 10.96 & 30 & 15.50 & 9.29 & 81 & 17.56 & 10.44 & 1.367 \\
\hline Yakın Arkadaşlar & 51 & 21.14 & 10.08 & 30 & 17.50 & 9.47 & 81 & 19.79 & 9.95 & 1.604 \\
\hline Toplam & 51 & 78.76 & 28.43 & 30 & 67.70 & 29.38 & 81 & 74.67 & 29.10 & 1.671 \\
\hline
\end{tabular}

Tablo 7'de görüldüğü gibi ergenlerin en çok yakın arkadaşlarından $(\bar{x}=19.79)$ ve öğretmenlerinden $(\overline{\mathrm{X}}=19.53)$ destek aldıklarına inandıkları; ailelerinden $(\bar{X}=17.98$, $\bar{X}=17.42)$ ve sınıf arkadaşlarından destek alan kızların ortalama puanlarının $(\bar{X}=18.76)$ erkeklerin ortalama puanından $(\bar{X}=18.76)$ biraz yüksek olduğu saptanmıştır. $(p>0.05)$ (Tablo 7).

\section{Tartışma ve Sonuç}

Gazi Erkek Yetiştirme ve Atatürk Çocuk Yuvası ve Kız Yetiştirme Yurdunda kalan 1318 yaş grubundaki araştırmaya dahil edilen ergenlerin algıladıkları sosyal destek ile geleceğe ilişkin beklentilerini ortaya koymak amacı ile planlanan ve yürütülen bu çalışmanın sonuçları; ergenlerin en çok yakın arkadaşlarından ve öğretmenlerinden destek algıladıklarını; yetiştirme yurdunda kalan kızların, erkek ergenlere göre öğretmen, aile 
ve sınıf arkadaşlarından algıladıkları sosyal desteğin daha yüksek olduğunu göstermiştir.

Sosyal destek algılarına ilişkin bulgular, Atatürk Çocuk Yuvası ve Kız Yetiştirme Yurdu ile Gazi Erkek Yetiştirme Yurdu'nda kalan ergenlerin öğretmenlerinden algıladıkları desteğin, cinsiyete göre farklılık gösterdiği saptanmıştır. Algılanan desteğin kızlarda daha yüksek olduğu gözlenmiştir.

Araştırmaya dahil edilen ergenlerin gelecek beklentilerine ilişkin genel bulgular ise, ergenlerin beklentilerinin en çok eğitim, iş ve ekonomik konularla ilişsili olduğunu, bunu sırası ile aile yaşamı ve sağlık ile ilgili gelecek beklentilerinin izlediğini göstermiştir.

Yetiştirme yurdunda kalan ve araştırma kapsamına alınan ergenlerin geleceğe ilişkin beklentileri içerisinde en çarpıcı sonuç; araştırmaya dahil edilen ergenlerin sosyal yaşama ilişkin gelecek beklentilerinin çok düşük olmasıdır. Araştırma kapsamına alınan ergenlerin sosyal destek sistemlerinden uzak kalmalarının bu durumun oluşmasında etkili olabileceği düşünülmektedir.

Yetiştirme yurtlarında, aileden uzak bir yaşam sürdürülmesinden dolayı, arkadaş, öğretmen ve okul ilişkileri önem kazanmakta, ailenin eksikliğinden dolayı ortaya çıkan boşluk, bu kişilerle kurulan iletişimle giderilmeye çalışılmaktadır.

Ergenlerin algıladıkları sosyal desteğin onların toplumsallaşmasında, ergenlik döneminde ortaya çıkan kimlik duygusunda bir bütünlüğe erişilmesinde, idealizmin yarattığı çatışmaların önlenmesinde ve ergenin sevgi arayışı ve beklentilerinin karşılanmasında önemli etkileri olduğu düşünülmektedir. Ergenlerin gelecekteki beklentileri onların gelecekle ilgili korkularını ortaya koymaktadır. Geleceğe ilişkin olumlu inançların, uzun dönemli planlar, daha iyi bir eğitime ve işe sahip olunacağına ilişkin inanç, okulda daha iyi bir sosyal ve duygusal uyum ile birbirine bağlı olduğu; ergenlerin algıladıkları sosyal destek arttıkça uyum sorunlarının azalacağı ve gelecek beklentilerinin daha olumlu olacağı bilinmektedir.
Yetiştirme yurdunda korunma altındaki çocukların sosyal yaşama uyum sorunlarıyla mücadele edebilmede ve onların geleceğe ilişkin olumlu beklentiler geliştirebilmelerine yardımcı olabilmek için;

$\checkmark$ Ergenlerin toplumla bütünleşmeleri ve sosyal destek algılarını olumlu yönde etkileyebilmek için yurtlarda aile ortamı oluşturulmalı, eğitimci ve uzmanlar çocukların yaşamı ile kendi yaşamlarını birleştirebilmeli ve günün her vakti ulaşılabilir olmalı,

$\checkmark$ Sosyal kolların işlevsel hale getirilmesi için aktiviteler, kurum içi ve kurum dışını kapsayacak biçimde düzenlenmeli; yurtların işlevselliği, uygun örgütsel yapı ve kurum personeline beklenen işlevler kazandırılarak sağlanmalı,

$\checkmark$ Yurtta hem personel ve hem de ergenler arasında güven ilişkisini kurmak ve ergenlerin sosyal destek ağını geliştirmek için grup çalışması faaliyetleri desteklenmeli,

$\checkmark$ Ergenlerin yaşadığı sorunlara baş etmede bir başka alternatif olarak da kurum odaklı hizmetler yerine aile odaklı hizmetlerin verilmesi, Sosyal Hizmetler ve Çocuk Esirgeme Kurumu'nun uyguladığı "Aileye Dönüş" ve "Aile Yanında Destek" projesine benzer projelerin hayata geçirilmesi sağlanmalıdır.

Ayrıca, ergenlerin bireyselliğinin güçlendirilmesinin yanısıra gelişimleri üzerinde etkili olacağı düşünülen konularda işlerliği kanıtlanmış hizmetiçi eğitim programlarının geliştirilmesinin, kurumdaki sosyal ortamları iyileştirmenin ve çalışanlarla ergenler arasında duyarlı ve sıcak ilişkiler gelişmesinin sağlanmasının gelişimleri üzerinde olumlu etkileri olacağı ve kurumda yetişmenin yaratacağı bir takım olumsuz psikolojik etkileri azaltabileceği düşünülmektedir.

Gelişmiş ülkelerin çoğunda uygulanan koruyucu aile bakım hizmetleri, aile ortamından uzak kalan çocukların toplumsallaşmalarında en başarılı yöntem olarak kabul edilmektedir. 


\section{Kaynakça}

Akman B (2002) Korunmaya muhtaç çocuklarla ailesi ile yaşayan çocukların kavram gelişimlerinin ve okula hazır bulunuşluk düzeylerinin karşılaştırılması, Toplum ve Sosyal Hizmet, 13 (1): 74-85.

Aydemir D, Hatipoğlu Sümer, Z. and Topçu, Ç. (2009) Predictors of Perceived Social Support Among Visually Impaired Adolescents. "The First International Educational Research Congress".

Bayraktar F (2007) Olumlu Ergen Gelişiminde Ebeveyn/Akran İlişkilerinin Önemi, Çocuk ve Gençlik Ruh Sağıı̆ı Dergisi, 14 (3): 157-166.

Büyüköztürk Ş (2002) Sosyal Bilimler İçin Veri Analizi El Kitabı. Pegem Yayıncılık, 179 s., Ankara.

Cebe F (2005) Sosyal Hizmetler ve Çocuk Esirgeme Kurumu Yetiştirme Yurtlarında Barınan Çocukların "Benlik Saygısı", "Depresyon", "Kaygı" Skorlarının Ailesi Yanında Kalan Çocuklarla Karşılaştırılması, İstanbul Üniversitesi Adli Tıp Enstitüsü Yüksek Lisans Tezi (Basılmamış), İstanbul.

Cılga I (1989) Korunmaya muhtaç gençlerin sorunları ve yetiştirme yurtları, T.C. Başbakanlık Gençlik ve Spor Genel Müdürlüğü, Gençlik Hizmetleri Daire Başkanlığı, Ankara.

Cobb S (1976) Social support as a moderator of life stres. Psychosomatic Medicine, 38: 300-314.

Çeçen AR (2008) Öğrencilerinin Cinsiyetlerine ve Anababa Tutum Algılarına Göre Yalnızlık ve Sosyal Destek Düzeylerinin İncelenmesi, Türk Eğitim Bilimleri Dergisi, 6 (3): 415-431.

Çevik G.B. ve Atıcı M. (2009) Lise 3. Sınıf Öğrencilerinin Benlik Saygılarının Bazı Değişkenler Açısından İncelenmesi, Uluslararası Insan Bilimleri Dergisi, 6 (1): 339352.

Demaray MK, Malecki, CK Davidson, LM ve ark. (2005) The Relationship Between Social Support and Student Adjustment: A Longitudinal Analysis, Psychology in The Schools, 42 (7): 691-706.
Gökler I (2007) Çocuk ve Ergenler için Sosyal Destek Değerlendirme Ölçeği Türkçe Formunun Uyarlama Çalışması: Faktör Yapısı, Geçerlik ve Güvenirliği. Çocuk ve Gençlik Ruh Sağlığı Dergisi, 14(2): 90-99.

Karataş K, Acar H, Cankurtaran Öntaş Ö. ve ark (2004) Türkiye'de Çocuğun Korunması: Osmanlı'dan Günümüze Çocuk Refahına Yönelik Düzenlemeler, Toplum ve Sosyal Hizmet, 15 (1): 15-25.

Kartal A ve Çetinkaya B (2009) Yüksekokul Öğrencilerinin Algılanan Sosyal Destek Durumları ve Sosyal Desteği Etkileyen Faktörler, Fırat Sağlık Hizmetleri Dergisi, 4(12): 3-20.

Köklü N ve Büyüköztürk Ş. 2000. Sosyal Bilimler İçin İstatistiğe Giriş. Pegem Yayıncılık, 195 s., Ankara.

Kürkçüoğlu BÜ, Şahin D, Acer D ve ark. (2010) Erken Çocukluk Eğitimi, Pegem A Yayıncılık, Ankara.

Malecki CK and Demaray, MK (2002) Measuring Perceived Social Support: Development of The Child and Adolescent Social Support Scale (CASSS), Psychology in the School, 39 (1): 118.

McWhirter EH and McWhirter, BT (2008) Adolescent Future Expectations of Work, Education, Family and Community: Development of a New Measure, Youth\&Society, 20 (10): 1-21.

Özdemir N, Sefer N ve Türkdoğan D (2008) Bir Sosyal Sorumluluk Projesi Örneği: Korunmaya Muhtaç Çocuklar, C.Ü. Sosyal Bilimler Dergisi, 32 (2): 283-305.

Şenocak H (2010) Korunmaya Muhtaç Çocuklara Sağlanan Bakım Yöntemleri, Sosyal Siyaset Konferansları Dergisi, 51 (2): 177-228.

Yardımcı F, Başbakkal Z (2008) Çocuk-Ergen Sosyal Destek Ölçeği'nin Türkiye'deki Geçerlik ve Güvenirlik Çalışması, Atatürk Üniversitesi Hemşirelik Yüksekokulu Dergisi, 12 (2): 41-50. 